UDC 316.61

LBC 88.3

\title{
THEORETICAL AND CONCEPTUAL APPROACHES AND RESULTS OF THE EMPIRICAL STUDY OF MEDICALIZATION PHENOMENON (LITERATURE REVIEW)
}

\author{
Tatyana G. Svetlichnaya \\ Northern State Medical University, Arkhangelsk, Russian Federation \\ Elena A. Smirnova \\ Cherepovets State University, Cherepovets, Russian Federation
}

\begin{abstract}
In modern society, human health is a component of the economic factor of labor and the main resource of work capacity, ensuring a high quality of human life. The development of medical science and public health as a social institution ensures the influence of medicine on a person's daily life, and is associated with the emergence of a social phenomenon of medicalization in society. Its essence lies in the perception of human life as a medical problem, a person - as a patient, and his body and consciousness - as objects of medical control and regulation. Social agents of medicalization are medical and pharmaceutical workers, teachers, journalists, sick and healthy people. The pharmaceutical companies and the media have a decisive role in maintaining and developing medicalization. At the same time, an increase in the scope of medicalization is not accompanied by an improvement in individual, group and public health, but on the contrary creates new risks and dangers in society. The situation is exacerbated by the risk of disrupting the balance of the social institutions of society.

The article presents data on the analysis of methodological grounds and scientific results of studying the phenomenon of medicalization as a subject of research in the social, medical and psychological sciences. The purpose of the study is to understand the phenomenon of medicalization from the standpoint of Western and domestic theoretical and conceptual approaches to its study and the terminology used for application in medical and social studies of health and public health. The justification of the negative social meaning of the phenomenon of medicalization which calls for the development of effective methods of coping is given. In the course of the research an analytical method was used in combination with a scientific and theoretical approach; materials of 58 $\simeq$ sources of literature including 28 scientific publications of foreign authors, were studied.
\end{abstract}

Key words: medicalization, social institution, social control, social role, doctor, pharmacist, patient.

УДК. 316.61

ББК 88.3

$$
\begin{gathered}
\text { ТЕОРЕТИКО-КОНЦЕПТУАЛЬНЫЕ ПОДХОДЫ } \\
\text { И РЕЗУЛЬТАТЫ ЭМПИРИЧЕСКОГО ИЗУЧЕНИЯ } \\
\text { ФЕНОМЕНА МЕДИКАЛИЗАЦИИ (ОБЗОР ЛИТЕРАТУРЫ) }
\end{gathered}
$$

\section{Татьяна Геннадьевна Светличная}

Северный государственный медицинский университет, г. Архангельск, Российская Федерация 


\section{Елена Алексеевна Смирнова}

Череповецкий государственный университет, г. Череповец, Российская Федерация

Аннотация. В современном обществе здоровье человека является составляющей экономического фактора труда и основным ресурсом трудоспособности, обеспечивающим высокое качество жизни человека. Развитие медицинской науки и здравоохранения как социального института обеспечивает влияние медицины на повседневную жизнь человека и связано с появлением в обществе социального феномена медикализации. Его суть заключается в восприятии человеческой жизни как медицинской проблемы, человека - как пациента, а его тела и сознания - как объектов медицинского контроля и регулирования. Социальными агентами медикализации являются медицинские и фармацевтические работники, педагоги, журналисты, больные и здоровые люди. Определяющее значение в поддержании и развитии медикализации принадлежит фармацевтическим компаниям и средствам массовой информации. При этом увеличение масштабов медикализации не сопровождается улучшением индивидуального, группового и общественного здоровья, а наоборот, создает в обществе новые риски и опасности. Ситуация усугубляется риском нарушения баланса социальных институтов общества.

В статье приведены данные анализа методологических оснований и научные результаты изучения феномена медикализации как предмета исследований в социальных, медицинских и психологических науках. Целью исследования явилось осмысление феномена медикализации с позиций западных и отечественных теоретикоконцептуальных подходов к ее изучению и используемого терминологического аппарата для применения в медико-социальных исследованиях здоровья и здравоохранения. Дано обоснование негативного социального смысла феномена медикализации, требующего разработки эффективных способов совладания. В ходе исследования был использован аналитический метод в сочетании с научно-теоретическим подходом; изучены материалы 57 источников литературы, в том числе 20 научных публикаций иностранных авторов.

Ключевые слова: медикализация, социальный институт, социальный контроль, социальная роль, врач, фармацевт, пациент.

\section{Постановка проблемы}

В совокупности общечеловеческих ценностей здоровье всегда занимало главное место, являясь важнейшим ориентиром в жизни любого человека [30, с. 3]. В условиях рыночной экономики социально-экономическое значение здоровья еще более возрастает. Оно становится необходимым условием повышения конкурентоспособности, выступая главной составляющей экономического фактора труда и основным ресурсом трудоспособности, определяющим степень производительности труда, обеспечивая в конечном итоге профессиональное долголетие человека и его благополучную старость [25, с. 156].

В настоящее время здоровье является предметом изучения целого комплекса медико-биологических и социальных наук: медицинских, социологических, психологических, педагогических, правовых, экономических и др. В совокупности современных научных знаний о здоровье ведущее место принадлежит науке социологии, являющейся фундаментальной основой для развития практически всех направлений медико-социальных исследова- ний в области здоровья и здравоохранения. Важность методологического значения социологии обоснована президентом РФ В.В. Путиным на расширенном заседании Государственного совета «О стратегии развития России до 2020 года» (2008): «социология, являясь наукой о становлении, развитии и отношениях социальных организаций и процессов, при исследовании здоровья должна быть сконцентрирована на социально обусловленных факторах, определяющих физическое и психическое здоровье индивида, социальной группы, общества в целом, на самосохранительном поведении и здоровом образе жизни его членов. Важным является изучение отношения к здоровью человека и общества как социальной ценности и социальных условий, в которых происходит его формирование. Болезнь необходимо рассматривать как состояние, препятствующее реализации психической, физиологической, репродуктивной и социальной жизнедеятельности индивида» [9, с. 7].

Развитие медицинской науки и здравоохранения как социального института тесно связано с появлением в современном обществе социального феномена медикализации. Его 
суть заключается в восприятии человеческой жизни как медицинской проблемы, человека как пациента, а его тела и сознания - как объектов медицинского контроля и регулирования $[18$, с. 10]. Психологической основой медикализации является патологизация сознания индивидов, социальных групп, общества в целом в результате формирования на всех уровнях социетальной системы специфического типа сознания - сознания пациентов.

Впервые термин «медикализация» в научный оборот введен более пятидесяти лет назад. Он предложен американским ученым Робертом Найем в 1960-е гг. для объяснения все возрастающей социальной и политической роли медицины и здравоохранения [53, p. 115-129]. Научный интерес к изучению влияния медицины на жизнь современного общества не ослабевает до сих пор [21, с. 262]. В настоящее время под «медикализацией» понимается «проникновение в массовое сознание медицинского языка и стиля мышления, медицинских концепций и представлений о причинах, формах протекания и лечения болезней, возрастание зависимости от медицины повседневной жизни и деятельности людей, закрепление медицинских “ярлыков" за некоторыми человеческими свойствами или типами поведения» [36, с. 159].

Осмысление феномена медикализации с позиций западных и отечественных теоретико-концептуальных подходов к ее изучению и используемого терминологического аппарата для применения в медико-социальных исследованиях здоровья и здравоохранения стало целью настоящего исследования. В ходе его проведения был использован аналитический метод в сочетании с научно-теоретическим подходом, проанализированы материалы 57 источников литературы, в том числе 20 научных публикаций иностранных авторов.

\section{Результаты и их обсуждение}

При определении смысла здоровья специалисты используют два основных подхода: узкодетерминированный медицинский и синергетический социальный. Медицинский подход наиболее ярко выражен в определении здоровья, данном Н.М. Амосовым (1913-2002), как суммы резервных возможностей основных функциональных систем организма. Социальный подход реализован в ставшем наиболее популярным в профессиональной медицинской среде определении ВОЗ (1948), согласно которому под здоровьем понимается состояние полного физического, психического и социального благополучия, а не только отсутствие болезней или физических дефектов [13, с. 10]. Целесообразность и правомерность широкого использования данного подхода объясняется сложностью и многоаспектностью феномена здоровья, отражающего исторические, демографические, социальные и политические процессы, уровень социокультурного и экономического развития общества, деятельность систем здравоохранения. В соответствии с данным методологическим подходом структура здоровья включает три компонента: физический, психический и социальный. Поскольку забота о продвижении здоровья осуществляется на всех трех структурных уровнях, постольку все они подвергаются воздействию феномена медикализации. При этом определяющее значение принадлежит медикализации социального компонента здоровья.

Здоровье как социальный феномен неразрывно связано с конкретной средой обитания, с различными сферами проявления жизнедеятельности человека, его основными целями и назначениями [15, с. 70]. На формирование конкретных социальных обстоятельств жизни общества оказывает влияние характер распределения денег, власти и ресурсов на глобальном, национальном и региональном уровнях вследствие проводимой государством социальной и экономической политики [28, с. 1]. В результате социальные условия, в которых люди рождаются, растут, живут, работают, стареют и умирают, включая деятельность систем здравоохранения, становятся социальными детерминантами здоровья. Они, выступая социальными объектами медикализации, придают этому феномену глобальный, всеобъемлющий характер.

Впервые научный интерес к изучению социальных процессов в ситуациях здоровья и болезни, а также к определению влияния медицины и здравоохранения на жизнь людей возник в конце XIX века. Э. Дюркгейм (1858$1917)$, изучавший норму и патологию в обще- 
стве, причины социальных болезней и способы их преодоления, не проводил различий между феноменами болезни и здоровья, воспринимая оба эти явления разновидностями одного и того же порядка, взаимно уточняющими и проясняющими друг друга [11, с. 23-32]. Их общий смысл ученый выразил в понятии «социальное здоровье», под которым понимал нормальное развитие жизненных сил индивида, социальной группы и общества в целом, их способность адаптироваться к условиям среды и использовать ее для своего развития. Позднее Т. Парсонс (1902-1979) предложил новый дифференцированный подход к определению социального смысла болезни и здоровья, согласно которому болезнь является формой «социального отклонения», а здоровье совокупностью оптимальных возможностей индивида по эффективному выполнению своих социальных ролей и задач [7, с. 40-44].

Дальнейшее изучение проблемы здоровья и болезни позволило ученым придти к пониманию социального смысла деятельности системы здравоохранения как института социального контроля. Впервые функция нормативной регуляции социальной роли врача была обоснована Т. Парсонсом [54, p. 428-479]. Данное заключение стало основанием для вывода ученого о значимости экспертного знания в реализации социальной роли врача и поддержании официального порядка в обществе, в котором медицина выступает важнейшим агентом социального контроля, одной из форм которого является терапия [47, p. 142].

Фрейдсон Элиот (1923-2005) дополнил существующие представления о смысле медицинской функции социального контроля, обосновывая ее как моральное действие, разграничивающее патологические поступки людей на две основные группы: за одни из них следуют меры юридического характера, за другие - медицинского [45, p. 1-419]. При этом в одни времена общество такие поступки криминализирует, в другие, определив болезнью, лечит, в третьи, воспринимая нормой, легализует [29, с. 323], но даже и в этом случае медицина сохраняет за собой функцию социального контроля. Так, например, отказ психиатров считать гомосексуальность болезнью не привел к полной демедикализации этого состояния [42, p. 101].
С течением времени влияние медицины и здравоохранения на жизнь людей неуклонно увеличивается. Этому способствует активное развитие фармацевтического производства, страховой медицины и внедрение в клиническую практику новых медицинских технологий. И хотя существенного улучшения индивидуального, группового и общественного здоровья не происходит, общество продолжает стремиться к обеспечению людей более гуманным социальным окружением, получившим специальное название «нормализации» $[24$, с. 26]. Одним из первых направлений гуманизации общества стала реформа психиатрической помощи или деинституционализация [10, с. 68].

Существенный вклад в понимание смысла данной социальной реформы внес американский психиатр Томас Шаш (1920-2012). Начиная с 1972 г. ученый посвятил свои научные труды изучению реакции психиатрии на различные формы социально неприемлемого поведения: суицид, педофилию, воровство и т. д. Полученные данные позволили ученому выявить наличие тесной взаимосвязи между расширением полномочий медицинских работников психиатрических служб, превращающим их в агентов поддержания общественного порядка, и медикализацией. Спустя почти 30 лет научные результаты проведенного исследования Т. Шаш опубликовал в монографии «Медикализация повседневной жизни» (2007). В ней на основе детального изучения взаимосвязи между принуждением и психиатрическим лечением ученый пришел к заключению о том, что медикализация - «это не медицина и не наука, это социально-семантическая стратегия, которая выгодна одним лицам и несет угрозы другим» [56, p. 129].

В 1972 г. Ирвин Зола (1935-1994) в статье «Медицина как институт социального контроля» продолжил обоснование влияния медицины и здравоохранения на жизнь общества. По мнению ученого, медицина, ставшая главным институтом социального контроля, вытесняет традиционные институты - религию и право, что ведет к медикализации жизнедеятельности человека. В результате здоровье обществом начинает восприниматься не как средство достижения блага, а как главное благо и цель человеческого существования [57, p. 487-504]. 
Три года спустя Питер Конрад (род. 1945) в научной работе «Выявляя гиперактивных детей: медикализация девиантного поведения» (1975) показал, что медикализация девиантного поведения детей ведет к индивидуализации социальных проблем, но не способствует росту гуманизации общества. Необоснованное навешивание медицинских ярлыков на различные предметы социального контроля становится причиной усиления власти экспертов и, как следствие, медикализации [41, p. 20]. Хорошо известно, что первичными агентами социального контроля, определяющими девиантный тип детского поведения, выступают семья и школа. В дальнейшем его определяют другие социальные группы: соседи, родственники, священнослужители и медики. Последние придают детской девиации статус медицинской проблемы. Это становится возможным в результате использования врачами с 1970-х гг. для постановки диагноза гиперактивности медикаментов. Изменение поведения ребенка после их применения на более социально приемлемое служит основанием для постановки диагноза гиперактивность.

Научные результаты дальнейшего изучения феномена медикализации Питер Конрад и Джозеф Шнайдер изложили в совместном научном труде «Девиация и ее медикализация: от испорченности к болезни» (1980), в котором обосновали связь медикализации социальных девиаций с историей медицины и социальных реформ в условиях капиталистического общества. В частности, они пришли к заключению о том, что в процессе эволюции рыночной системы экономических отношений телесное и душевное здоровье превращается в высшую ценность, а проявления любых форм нездоровья - в отклонения от нормы. Признание здоровья экономической ценностью превращает медицину в выгодное дело (бизнес), а медикализацию - в инструмент создания новых рынков товаров и услуг [38, p. 263-265].

Определенный вклад в продолжение изучения проблемы медикализации внес Иван Иллич (1926-2002). В научной монографии «Медицинская Немезида: экспроприация здоровья〉 (1976) [47, с. 1-201] и последующей статье с почти аналогичным названием «Медицинская Немезида» (2003) [46, p. 919-922] И. Иллич делает вывод об опасности и даже вреде медицины для здоровья. Обоснованием сделанного ученым вывода служит нередкое отсутствие пользы от медицинских вмешательств, часто сопровождающихся появлением побочных эффектов, а также возможность получения медицинскими работниками полного социального контроля над людьми. Наиболее известными примерами нанесения человеку вреда медициной являются участие врачей в пытках и издевательствах, использование людей в клинических испытаниях, связанных с повышенным риском для здоровья и жизни или проводимых против их воли, а также применение непроверенных методов или средств лечения и др.

Увеличение расходов на здравоохранение вследствие активного вмешательства фармацевтических компаний в повседневную жизнь людей становится дополнительным фактором медикализации бюджета здравоохранения, как государственного, так и личного. Превращение здоровья в экономический товар и предмет купли-продажи, а также получение все большим числом людей статуса пациента ведет к сокращению производительных сил общества и уменьшению его продуктивности. Способом выхода из сложившейся ситуации, по мнению И. Иллича, является введение публичного контроля над профессиональной медициной, а необходимым условием - возвращение людям уважения к собственной природе и осознание здоровья как результата добродетельного образа жизни.

Наиболее глубокой теоретической разработке проблемы медикализации посвящены научные труды французского философа и историка наук о человеке Мишеля Фуко (19261984). В научной работе «Рождение клиники» ученый изложил результаты изучения истории медицины, компетенция которой с течением времени выходит за пределы «техник врачевания и необходимых умений», направленных на облегчение страданий человека [43, p. 67]. В результате такой трансформации объектами исследования современной медицины наряду со здоровьем и болезнью, нормой и патологией становятся категории жизни и смерти, души и тела [36, с. 155-160]. В последующих научных работах ученый дает характеристику феномена медикализации с четырех 
сторон: эпистемологической, социальной, политической и исторической.

Первая - эпистемологическая. Основной вывод - причиной медикализации является увеличение объема научных знаний о человеке. Первые научные представления о физической норме и патологии человека возникли в XIX в. благодаря развитию науки патологической анатомии. Последующее расширение социальных практик клинического наблюдения существенно увеличило сферу получения знаний о человеке, а введение систем регистрации медицинских данных с использованием методов статистического анализа позволило проводить медицинские оценки с помощью количественных параметров, что способствовало объективизации научных данных [33, с. 71].

Вторая - социальная. Основной вывод развитие медикализации тесно связано с появлением медицинских практик социального разделения общества. Расширение сети медицинских учреждений, в том числе специализированных, привело к разделению людей на больных и здоровых. Отдельные лица, семьи и даже социальные группы, превратившись в объекты медицинского наблюдения, постепенно отделились от тех, кто подлежал воздействию других социальных институтов религии, права, образования [32, с. 413].

Третья - политическая. Основной вывод - медикализация является политической технологией. В условиях сохраняющегося социального контроля медицины над физической, эмоциональной и интеллектуальной жизнью людей медикализация позволяет заменить открытые формы социального насилия на «мягкие формы» социального принуждения [44, p. 176].

Четвертая - историческая. Основной вывод - усилению медикализации способствует рост медицинского контроля и широкое распространение медицинских представлений, вызванных развитием рыночных отношений в условиях роста промышленного производства, бюрократизма и рационализма, в которых человеческое здоровье понимается как экономический товар, являясь объектом медицинского предпринимательства и, как следствие, предметом торговли [34, с. 101].

Обобщая результаты проведенного анализа, М. Фуко определяет медикализацию не только как социальный феномен, вследствие которого «человеческое существование, поведение и тело интегрируются во все более густую сеть медицинского сервиса, и сеть эта захватывает все большее количество вещей», но и как дискурсивную стратегию, призванную легитимировать и поддерживать происходящие в обществе экономические, политические и социальные процессы. Исходя из данного определения, М. Фуко рассматривает медицину как инстанцию, осуществляющую контроль над индивидами, но не через систему медицинских учреждений и формальных медицинских требований, а посредством функционирования медицинского дискурса, распространение которого за рамки профессионального поля содействует «формированию медицински бдительного сознания каждого индивида» $[34$, c. 100$]$. В этой связи появление возможности выбора лекарственных препаратов и самостоятельной заботы о своем здоровье, позволяющей избежать медицинского контроля, учеными рассматривается как положительный эффект медикализации [55, p. 290].

В настоящее время медикализацию как процесс распространения научного медицинского знания за пределы профессионального дискурса и его активного функционирования в медийной, политической и повседневной сфеpax жизни общества понимают многие современные ученые [26, с. 26-51; 37, с. 53-54]. В частности, Ханс Баер, Мерилл Зингер и Ида Сассер характеризуют медикализацию как одно из проявлений «биомедицинской гегемонии», навязывающей людям биомедицинские нормы, ценности и представления. Последнее становится возможным благодаря особому статусу научной медицины, основанной на доказательствах. Вследствие этого медицинское экспертное знание пациентами принимается добровольно и не воспринимается как проявление власти. Данное обстоятельство препятствует критическому восприятию медицинского знания как поля власти, как определенной идеологии, которая «воспроизводит неравное распределение власти между социальными классами» [31, с. 250].

Теоретическое изучение проблемы медикализации сопровождалось проведением многочисленных эмпирических исследований. Наиболее изученной является проблема ме- 
дикализации здоровья и образа жизни женщин. Описанию жесткого технократического контроля современной медицины над жизнью женщин посвящена научная работа американского ученого Эмили Мартин «Тело женщины: культурный анализ репродукции» (1987) [53, p. 1-276].

Результаты эмпирического изучения медикализации женского репродуктивного опыта подробно изложены в научных работах Маргарет Локк [48, p. 303-347; 49, p. 1-439]. Исторически первым событием в жизни женщин, подвергшимся медикализации, являются роды. В последующем функция родовспоможения от женщин-повитух постепенно перешла к медицинским работникам. Медикализация началась после усиления медицинского контроля над женской репродуктивностью. В частности, распространение дорогостоящих технологий оплодотворения in vitro способствовало медикализации проблемы бесплодия [40, p. 158-176]. С течением времени процесс медикализации охватил все этапы жизненного цикла женщины - младенчество, детство, юность, зрелость и старость [2, c. 366]. В научном труде «Столкновения со старением: мифологии менопаузы в Японии и Северной Америке» (1993) М. Локк описывает различные формы отношения к женскому старению в североамериканском и японском обществах. В XX в. увеличение продолжительности жизни женщин по сравнению с мужчинами и их старение сопровождается не только ростом экономических трудностей, но и появлением новых форм медикализации. Их возникновение связано с пониманием менопаузы как физиологического состояния, а старения - как изменения гормонального статуса. Определение рисков развития остеопороза, слабоумия, болезней сердца и сосудов у пожилых женщин привело к медикализации состояний, приходящих на смену женской репродуктивной активности. Фармацевтические компании незамедлительно предложили препараты, позволяющие снизить эти риски [50, p. 364].

На рубеже XX-XXI вв. научные интересы ученых сосредоточиваются на изучении медицинского поведения различных категорий людей, попавших в кризисную ситуацию (ВИЧ-инфицированных, онкологических больных, жителей территорий, подвергшихся эко- логическому загрязнению). В коллективной монографии под редакцией Маргарет Локк и Патришии Коуферт «Прагматичные женщины и телесная политика» (1998) ученые отмечают возрастание влияния медицины на жизнь людей, которые не только не отказываются от медицинского контроля (демедикализация), a, наоборот, стремятся к еще большей медикализации (супермедикализация). В результате ученые приходят к формулированию новых научных вопросов: какова реальная власть врачей, когда они сами оказываются агентами фармацевтических компаний? и насколько изменяется общество, когда медикализация сопровождается появлением новых феноменов супермедикализации и демедикализации? $[51$, p. 255].

Первые попытки описания происходящих в современном обществе изменений предприняты в 1986 г. немецким социологом Ульрихом Беком (1944-2015), обобщившим смысл осуществляемых социальных преобразований в новом понятии «общество риска». Его суть заключается в повсеместном ощущении постоянно возникающих новых опасностей и рисков для здоровья. Немаловажное значение в их увеличении принадлежит медицине. Несмотря на успехи в диагностировании опасных состояний и сокращении числа случаев острых заболеваний, медицина до сих пор не в состоянии предотвратить появление новых и возврат старых болезней [4, с. 11]. При этом ответственными за создание новых рисков и опасных состояний становятся врачи, являющиеся основными агентами медикализации. На риск моделирования врачами медицинских состояний с участием фармацевтических компаний, ищущих новых потребителей своей продукции, обращает внимание Линн Пайер $[56$, p. 190] в научном труде «Торговцы болезнями: как доктора, фармацевтические компании и страховые агенты заставляют вас чувствовать себя больными» (1992).

Продолжение изучения проблемы медикализации рисков и опасных состояний связано с научными исследованиями М. Локк [51, p. 239-266], посвященными анализу рынка новых биомедицинских технологий. К ним наряду с лекарственными препаратами относятся генетический скрининг, компьютерная медицинская диагностика и т. д. Появление но- 
вых рисков М. Локк связывает, в частности, с неблагоприятными результатами генетического анализа, являющимися основанием для принятия решения о прерывании беременности. При этом генетический анализ, основанный на учете вероятностных данных, не являясь абсолютно точным, становится причиной возникновения новой опасной формы дискриминации - генетической. Наиболее известным примером генетического контроля является международный проект «Геном человека». Использование результатов генетического тестирования для отнесения людей к группе больных или подверженных высокому риску заболевания ведет к усилению генетической дискриминации. Особенно высокому риску подвергаются люди из малообеспеченных слоев населения, проживающие вдалеке от медицинских центров, получающие результаты исследования без необходимых консультаций и, как следствие, не всегда способные адекватно воспринять информацию о своем будущем заболевании.

Полученные результаты позволили М. Локк совместно с Вин-Ким Нгуеном в научном труде «Антропология биомедицины» (2010) прийти к заключению о том, что происходящие в обществе изменения связаны с внедрением в медицинскую практику новых биомедицинских технологий. Традиционный медицинский контроль в форме принудительного лечения и госпитализации в современном обществе почти исчезает, на смену медикализации патологии и девиации приходит медикализация благополучия. С физического, психического и социального уровней она распространяется на уровень генов, которые становятся главным «воплощением риска». Это несет с собой новые риски и опасности, прогноз которых неизвестен. Вследствие широкого распространения процесса медикализации основным содержанием жизни современного человека становится постоянное переживание психоэмоционального стресса. Ситуация усугубляется использованием в государственной политике развитых стран неолиберального подхода, направленного на сокращение объемов государственной поддержки различных категорий нуждающихся, что превращает болезнь и здоровье в личное дело каждого [52, p. 246].
Последующее эмпирическое изучение феномена медикализации связано с анализом факторов, влияющих на потребительское поведение на фармацевтическом рынке. Питер Конрад и Валери Лейтер в совместной научной статье «Медикализация, рынки и потребители» (2004) обосновали появление новых медицинских проблем и патологических состояний в условиях постоянного выведения на рынок новых фармацевтических препаратов. Они заключаются в отсутствии у пациентов полного объема медицинской информации о применении медикаментов, самостоятельном принятии решения о выборе лекарственных средств без обращения к врачу, игнорировании медицинских рекомендаций, а также в недостаточной информированности о последствиях бесконтрольного применения лекарственных средств. Увеличению объемов потребления лекарственных средств способствует переход от доминирующей роли врача к доминированию фармацевтических компаний, агентов страховой медицины, поставщиков новых биомедицинских технологий вследствие постоянного появления на рынке новых лекарственных средств и медицинских услуг.

Спустя 30 лет от начала исследования проблемы медикализации детской гиперактивности, синдрома рассеянного внимания, андропаузы, облысения и ректильной дисфункции Питер Конрад обобщил полученные результаты в труде «Медикализация общества: о трансформации человеческих состояний в излечимые расстройства» (2007), определив феномен медикализации как способ социального конструирования реальности [39, p. 33-49, 51-69].

Для отечественной теории и практики здравоохранения феномен медикализация является достаточно новым явлением. Впервые в отечественной научной литературе понятие медикализации описано академиком РАМН А.В. Решетниковым в фундаментальной работе «Социология медицины» [25, с. 242-249]. Важность изучения проблемы медикализации, по мнению ученого, состоит в непрерывном углублении и расширении этого процесса, следствием которого является усиление влияния здравоохранения как института социального контроля на жизнь общества. Оно сопровождается формированием зависимости па- 
циентов от врачей и созданием в обществе дополнительных социальных рисков, к которым оно еще пока не готово. А.В. Решетников, в частности, отмечает, что признание здоровья экономической ценностью ведет к неблагоприятным социальным последствиям. В частности, принятие обеспеченными людьми личной ответственности за свою жизнь и здоровье снимает ответственность с правительства страны за здоровье граждан, освобождая от необходимости заботиться об их здоровье и благополучии. В результате сфера бесплатного государственного здравоохранения в стране постепенно сужается, а число больных и заболевших среди самых незащищенных слоев общества неуклонно растет.

В настоящее время научный и практический интерес отечественных ученых к изучению феномена медикализации постоянно возрастает, что отражается в увеличении числа публикаций по этой проблеме. Одновременно расширяется круг подлежащих изучению научных тем. Он включает в себя медикализацию общества, повседневности, образа жизни, детства, материнства, старости, сексуальности, климакса, медиа-дискурса [17, с. 115], потребления лекарственных средств [23, с. 16] и т. д.

Первые эмпирические исследования феномена медикализации в России стали проводиться в 1990-е гг. и начались с изучения медикализации репродуктивного здоровья женщин в рамках совместного российско-американского проекта. Его результаты М. РивкинФиш и В. Самохвалов опубликовали в статье «Сексуальное образование и развитие личности: переосмысление профессиональной власти» (2009), посвященной обоснованию профессиональной экспертизы как инструмента контроля над индивидами на основании изучения «способов, с помощью которых медицинское экспертное знание практикует и легитимирует свою власть» [26, с. 25]. Факторам формирования медицинской экспертной власти посвящены работы Т. Бараулиной (2002) и О.М. Сасункевича (2014), рассматривающих материнство как медицинскую [2, c. 366] и политическую [27, с. 412] категорию для объяснения того, как установление медицинского контроля над материнством обеспечивает формирование профессиональной вла- сти по поддержанию социального порядка в обществе.

С ростом медицинских знаний о норме и патологии женского воспроизводства происходит усиление медикализации этого процесса. Изучению его эффектов посвящены многие работы отечественных ученых. Так, избыточная медикализация женской репродукции, по мнению А.Н. Боязитовой [5, с. 8], Г.Ю. Бударина, с одной стороны, создает предпосылки для злоупотребления женщиной своим состоянием, а с другой - увеличивает ее зависимость от медицинских работников и производителей лекарственных средств. Г.Ю. Бударин (2005), определяя медикализацию как необходимость, способствующую лечению болезней, обращает внимание на ее низкий социальный эффект, практически не оказывающий существенного влияния на изменение социального статуса и социального контекста жизни человека $[6$, с. 20]. Более того, медицинские решения социальных проблем (например, насилия в семье), способствуя медикализации повседневной жизни, усугубляют неблагоприятную социальную ситуацию, являясь причиной ее постоянного воспроизводства.

М.С. Агаджиева (2010), изучавшая роль врачей и женщин-пациенток как агентов медикализации предменструального синдрома, выделяет положительные (облегчение страдания) и отрицательные (необоснованное расширение медицинских вмешательств) эффекты медикализации, а также разное отношение к ним обеих групп участников лечебного процесса. Так, женщины-пациентки заинтересованы в медикализации предменструального синдрома для повышения качества жизни и не заинтересованы в увеличении зависимости от врачей и лекарственных средств. Врачи заинтересованы в индивидуализации лечения предменструального синдрома и не заинтересованы в отнесении страдающих им женщин к группе больных [1, с. 5].

Основными агентами медикализации материнства выступают врачи акушеры-гинекологи, фармацевтические работники и беременные женщины. При этом первые две группы участников являются активными, третья пассивными агентами медикализации [19, c. 12-15]. А.В. Мызгин (2012), изучавший социальные риски медикализации беременнос- 
ти, к ним относит: низкую степень доверия врачу, плохую информированность по применению лекарственных средств, слабую ориентированность в их номенклатуре, невозможность приобретения дорогих импортных препаратов, отсутствие полноценной коммуникации с провизором или фармацевтом при выборе препарата $[6$, с. 8]. Основной причиной социальных рисков медикализации беременности является высокая степень бюрократизации профессиональной ответственности врачей акушеров-гинекологов [22, с. 23], для которых ответственность перед пациентом является менее значимой, чем перед администрацией [29, с. 329]. Ситуация усугубляется ограничением доступа пациенток к медицинской информации, контролируемого медицинскими работниками, в том числе занимающими административные должности [12, с. 189 ; 29, с. 329].

Наряду с изучением медикализации материнства отечественные ученые исследуют процесс медикализации детства [20, с. 5-6, 9, $11,20]$. В частности, О.Н. Михайлова (2008) к агентам медикализации детства относит медицинских и фармацевтических работников, педагогов-воспитателей и родителей; к причинам рисков - избыточность или недостаточность медицинских вмешательств; к отрицательным эффектам медикализации - отсутствие индивидуального подхода, подмену ценностей здоровья ценностями бизнеса, некомпетентность агентов медикализации, низкую научно-техническую обеспеченность, непрогнозируемость некоторых медицинских вмешательств; к положительным эффектам - своевременную и всестороннюю оценку симптомов заболеваний, своевременное осуществление медицинских вмешательств, сохранение здоровья и спасение жизни ребенка.

Особенно подверженными медикализации являются пожилые люди [14, с. 15-16]. В результате ухудшения здоровья, снижения социальной активности и недостатка социальных ролей они, часто воспринимая медицинскую помощь как заботу и внимание, становятся активными потребителями неоправданно большого количества лекарственных средств и товаров медицинского назначения [14, с. 7].

Значительный вклад в выявление негативных эффектов медикализации внесен С.А. Веш- невой (2016), изучавшей медикализацию наркоманий и социализацию наркозависимых. Ею, в частности, установлены отсутствие дифференцированного подхода к лечению зависимых от различных групп психоактивных веществ, избыточность медикаментозных назначений, высокая стоимость лекарственных средств. К факторам, способствующим расширению медикализации в наркологии, С.А. Вешнева относит: повышение толерантности общества к зависимостям, наличие латентной связи между медикализацией и социальной дискриминацией, появление новой группы социальных агентов, способной извлекать выгоду из запретов на использование определенных препаратов и создавать новых пациентов [8, с. 10].

Изучению роли фармацевтических компаний как социальных агентов медикализации посвящена научная работа А.В. Басова (2008), доказавшего их влияние на расширение процесса медикализации, усугубляемого социальными рисками неконтролируемого потребления лекарственных средств [3, с. 4, 6-8].

Большое значение для понимания смысла медикализации и факторов, способствующих ее распространению, имеет работа О.С. Макаровой (2015), изучавшей лингвистический аспект данного явления. Она определяет медикализацию как информационно-коммуникативный процесс, заключающийся в постоянном введении в общественное коммуникативное пространство новых знаний о медицине, болезнях, здоровом образе жизни и направленный на формирование в сознании целевой аудитории образа новых патологических состояний, требующих медицинского и медикаментозного вмешательства $[18$, с. 2]. Классификацию социальных агентов медикализации O.C. Макарова дополняет группировкой на первичные (медицинские и фармацевтические работники) и вторичные (журналисты, внедряющие медицинскую информацию в массовое сознание с помощью средств масс-медиа). При этом популяризация медицинского знания может сопровождаться созданием новой патологии или замещением одной патологии другой.

Продолжая изучение темы влияния средств массовой информации на общественное сознание, О.М. Сасункевич выделяет три наиболее важные информационно-коммуникативные стратегии медикализации материнства 
[27, с. 409-410]. Первая стратегия заключается в привлечении врачей в качестве экспертов по различным медико-социальным проблемам материнства: планирования семьи, бесплодия, кормления грудью, обсуждения отказа от рождения детей, причин возникновения детских страхов и т. д. Второй стратегией является размещение информационных материалов в печатных средствах массовой информации в рубриках, посвященных здоровью. Третья стратегия состоит в медицинском решении медико-социальных проблем материнства: планирования семьи, бесплодия, женского здоровья, распространения инфекций, передаваемых половым путем, грудного вскармливания, рака груди и т. п.

А.В. Кузнецов (2009) дополняет представления о медикализации как информационно-коммуникативном процессе, выделяя ее позитивные и негативные эффекты. К первым он относит участие средств массовой информации в профилактической работе, ко вторым - использование необъективной или недостоверной медицинской информации, неполное или одностороннее освещение событий в медицине и здравоохранении, а также преследование экономических целей в ущерб социальным [16, с. 6,12$]$.

\section{Заключение}

Таким образом, анализ научной литературы по теме исследования свидетельствует о глубокой теоретической разработанности феномена медикализации и наличии хорошо сформированного терминологического аппарата для его изучения. Термин медикализация имеет негативный социальный смысл и означает определение состояния или поведения человека как медицинской проблемы, требующей медицинского разрешения. Понятие отражает современную негативную тенденцию к медицинскому объяснению жизненных коллизий и социальных ситуаций, возникающих на всех этапах жизненного пути человека. Суть феномена заключается в формировании у людей сознания пациентов, полностью зависимых от медицинских и медикаментозных вмешательств. Социальными агентами медикализации являются медицинские и фармацевтические работники, педагоги, журналисты, боль- ные и здоровые люди. Определяющее значение в поддержании и развитии медикализации принадлежит фармацевтическим компаниям и средствам массовой информации. Неуклонное увеличение масштабов медикализации не сопровождается улучшением индивидуального, группового и общественного здоровья, а, наоборот, создает в обществе новые риски и опасности. Ситуация усугубляется риском нарушения баланса социальных институтов общества. Вместе с тем, несмотря на достигнутые результаты в научной разработке проблемы медикализации, недостаточно исследованными остаются способы совладания с данным негативным социальным явлением, способные не только сдержать его рост, но и оказать эффективное противодействие дальнейшему распространению.

\section{СПИСОК ЛИТЕРАТУРЫ}

1. Атагаджиева, М. С. Социальные и клинические особенности медикализации предменструального синдрома : автореф. дис. ... канд. мед. наук / Атагаджиева Мадина Сиражутдиновна. - Волгоград, 2010. $-27 \mathrm{c}$.

2. Бараулина, Т. Моральное материнство и воспроизводство женского опыта / Т. Бараулина // В поисках сексуальности : сб. ст. / под. ред. Е. Здравомысловой и А. Темкиной. - СПб. : Дмитрий Буланин, 2002. - С. 366-405.

3. Басов, А. В. Фармацевтические компании как социальные агенты медикализации : автореф. дис. ... канд. социол. наук / Басов Александр Викторович. - Волгоград, 2008. $-26 \mathrm{c}$.

4. Бек, У. Общество риска. На пути к другому модерну / У. Бек. - М. : Прогресс-Традиция, 2000. $383 \mathrm{c}$.

5. Боязитова, А. Н. Медикализация как социальный процесс : автореф. дис. ... канд. мед. наук / Боязитова Антонина Николаевна. - Волгоград, 2007. - 30 c.

6. Бударин, Г. Ю. Социальные принципы нормативного регулирования медицинской деятельности : автореф. дис. ... д-ра социол. наук / Бударин Глеб Юрьевич. - Волгоград, 2002. - 27 с .

7. Верминенко, Ю. В. Социологическая интерпретация здоровья / Ю. В. Верминенко // Социальные проблемы. - 2008. - № 1. - С. 37-44.

8. Вешнева, С. А. Медикализация наркоманий и социализация наркозависимых: концепция взаимосвязи : автореф. дис. ... д-ра мед. наук / Вешнева Светлана Александровна. - Волгоград, 2016. - 47 с.

9. Выступление Президента Российской Федерации В.В. Путина на расширенном заседании 
Государственного совета «О стратегии развития России до 2020 года» // Интеллектуальная собственность. Промышленная собственность. - 2008. № 4. - C. 4-20.

10. Дуганов, М. Д. Опыт постиндустриальных стран в реструктуризации медицинской помощи и уроки для России / М. Д. Дуганов, А. А. Шабунова, К. Н. Калашников // Проблемы развития территории. - 2016. - № 2 (82). - С. 65-81.

11. Дюркгейм, Э. Социология. Ее предмет, метод, предназначение / Э. Дюркгейм ; пер. с фр., сост., послесл. и примеч. А. Б. Гофмана. - М. : Канон, 1995. - $352 \mathrm{c}$.

12. Здравомыслова, Е. А. «Врачам я не доверяю, но...». Преодоление недоверия к репродуктивной медицине / Е. Здравомыслова, А. Темкина // Здоровье и доверие: гендерный подход к репродуктивной медицине. - СПб. : Изд-во ЕУСПб, 2009. C. 179-210.

13. Карпов, А. М. Здравствуйте, если хотите. Образовательные основы интеграции медицины, экологии, образа жизни и власти / А. М. Карпов. Казань : Мед. лит., 2008. - 223 с.

14. Кесаева, Р. Э. Социологический анализ медико-социальной работы с пожилыми людьми : автореф. дис. ... канд. социол. наук / Кесаева Журета Эльбрусовна. - Волгоград, 2008. - 25 с.

15. Краткий словарь по социологии / под общ. ред. Д. М. Гвишиани, Н. И. Лапина. - М. : Политиздат, 1988. - С. 77.

16. Кузнецов, А. В. Социальные взаимодействия врачей, пациентов и СМИ в процессе медикализации : автореф. дис. ... канд. социол. наук / Кузнецов Алексей Викторович. - Волгоград, 2009. - 27 с.

17. Лехциер, В. Л. Эффекты медикализации и апология патоса / В. Л. Лехциер // Вестник Самарской гуманитарной академии. Сер. «Философия. Филология». - 2006. - № 1 (4). - С. 113-125.

18. Макарова, О. С. Лингвистический аспект медикализации: постановка проблемы / О. С. Макарова // Ученые записки Новгородского государственного университета имени Ярослава Мудрого. -2015 . - № 2. - С. 10-11.

19. Медикализация беременности / А. В. Мызгин, А. В. Андеева, Е. П. Шевцова, Ю. А. Шатилов // Мать и дитя в Кузбассе. - 2014. -№ 3 (58). C. $12-15$.

20. Михайлова, О. Н. Медикализация детства: социологический анализ : автореф. дис. .... канд. мед. наук / Михайлова Ольга Николаевна. - Волгоград, 2008.-23 c.

21. Михель, Д. В. Медикализация как социальный феномен / Д. В. Михель // Вестник СГТУ. 2011. - № 4 (60). - Вып. 2. - С. 256-263.

22. Мызгин, А. В. Социальные риски медикализации беременности : автореф. дис. ... канд. со- циол. наук / Мызгин Алексей Владимирович. - Волгоград, 2012. $-24 \mathrm{c}$.

23. Петров, В. И. Новые технологии, регулирование, стандартизация и фармакоэкономика в сфере обращения лекарственных средств / В. И. Петров, А. Н. Луцевич, О. В. Решетько. - М. : Медицина, 2006. -456 c.

24. Реформа больниц в новой Европе / Ж. Фигерас, М. Макки, Э. Моссиалос, Р. Б. Солтман. М. : Весь Мир, 2002. - 320 с.

25. Решетников, А. В. Социология медицины / А. В. Решетников. - М. : ГЭОТАР - Медиа, 2007. $256 \mathrm{c}$.

26. Ривкин-Фиш, М. Сексуальное образование и развитие личности: переосмысление профессиональной власти / М. Ривкин-Фиш, В. Самохвалов // Здоровье и доверие: гендерный подход к репродуктивной медицине : сб. ст. / под ред. Е. Здравомысловой и А. Темкиной. - СПб. : Изд-во Европ. ун-та в С.-Петербурге, 2009. - С. 21-51.

27. Сасункевич, О. М. Медикализация дискурса о материнстве в белорусских медиа / О. М. Сасункевич // Журнал исследований социальной политики. - 2014. - Т. 7, № 3. - С. 405-418.

28. Социальные детерминанты здоровья. Электрон. текстовые дан. - Режим доступа: http:// www.who.int/social_determinants/ru/ (дата обращения: 13.01.2017). - Загл. с экрана.

29. Темкина, А. Медикализация репродукции и родов: борьба за контроль / А. Темкина // Журнал исследований социальной политики. - 2014. - Т. 12, № 3. - С. 321-336.

30. Терентьев, О. В. Здоровье человека как объект философско-аксиологического анализа : автореф. дис. ... канд. филос. наук / Терентьев Олег Владимирович. - М., 2008. - 26 с.

31. Филлипс, Л. Дискурс-анализ: теория и метод / Л. Филлипс, М. В. Йоргенсен. - Харьков : Гуманитарный центр, 2008. - 336 с.

32. Фуко, М. История безумия в классическую эпоху / М. Фуко. - СПб. : Университетская книга, 1997. $-576 \mathrm{c}$.

33. Фуко, М. Рождение клиники / М. Фуко. М. : Смысл, 1998. - 310 с.

34. Фуко, М. Рождение социальной медицины / М. Фуко // Интеллектуалы и власть: избранные политические статьи, выступления и интервью. Ч. 3. - М. : Праксис, 2006. - С. 79-107.

35. Чернышкова, Е. В. Активный образ жизни в пожилом возрасте: медико-социальные стратегии, риски, практики / Е. В. Чернышкова, Е. А. Андриянова. - Саратов : Наука, 2012. - 258 с.

36. Шлюмбом, Ю. Введение. История медицины: актуальные тенденции и перспективы / Ю. Шлюмбом, М. Хагнер, И. Сироткина // Болезнь и здоровье: новые подходы к истории медицины - СПб. : 
Европ. ун-т в С.-Петербурге : Алетейя, 2008. C. $155-160$.

37. Шухатович, В. Р. Медикализация / В. Р. Шухатович // Социология : энциклопедия / сост. А. А. Грицанов, В. Л. Абушенко, Г. М. Евелькин [и др.]. Мн. : Книжный Дом, 2003. - С. 1312.

38. Conrad, P. Deviance and Medicalization: From Badness to Sickness / P. Conrad, J. W. Schneider. Philadelphia: Temple University Press, 1992. - P. 263-265.

39. Conrad, P. Identifying Hyperactive Children: The Medicalization of Deviant Behavior / P. Conrad. Burlington : Ashgate, 2006. - $160 \mathrm{p}$.

40. Conrad, P. Medicalization, Markets and Consumers / P. Conrad, V. Leiter // Journal of Health and Social Behavior. - 2004. - Vol. 45 (Extra Issue). P. 158-176.

41. Conrad, P. The Discovery of Hyperkinesis: Notes on the Medicalization of Deviant Behavior / P. Conrad // Social Problems. - 1975. - Vol. 23 (1). P. $12-21$.

42. Conrad, P. The Medicalization of Society: On theTransformation of Human Conditions into Treatable Disorders / P. Conrad. - Baltimore : The Johns Hopkins University Press, 2007. - 205 p.

43. Foucault, M. Naissance de la clinique / M. Foucault. - Paris : Presses Universit. de France, 1963. $-212 \mathrm{p}$.

44. Foucault, M. The Politics of Health in the Eighteenth Century/ M. Foucault // Power/Knowledge: Selected Interviews and Other Writings, 1972-1977 / ed. by C. Gordon. - N. Y. : Pantheon, 1980. - P. 166-182.

45. Freidson, E. Profession of Medicine: A Study of the Sociology of Applied Knowledge / E. Freidson. N. Y. : Dodd, Mead Gabe, 1970. -419 p.

46. Illich, I. Medical Nemesis / I. Illich // Journal of Epidemiology and Community Health. - 2003. Vol. 57 (12). - P. 919-922.

47. Illich, I. Medical Nemesis: The Expropriation ofHealth / I. Illich.-N. Y. : Pantheon Books, 1976. -201 p.

48. Lock, M. An Anthropology of Biomedicine / M. Lock, V.-K. Nguyen. - Oxford: Blackwell, 2010. P. 303-347.

49. Lock, M. Encounters with Aging: Mythologies of Menopause in Japan and North America / M. Lock. - Berkeley: University of California Press, 1993. $-439 \mathrm{p}$.

50. Lock, M. Pragmatic Women and Body Politics / M. Lock, P. Kaufert. - Cambridge : Cambridge University Press, 1998. 364 p.

51. Lock, M. Utopias of Health, Eugenics, and Germline Engineering // M. Lock, M. Nichter // New Horizons in Medical Anthropology: Essays in Honour of Charles Leslie. - Reading : Harwood Academic, 2002. -P. 239-266.
52. Martin, E. The Woman in the Body: ACultural Analysis of Reproduction / E. Martin. - Boston : Beacon Press, 2001. -276 p.

53. Nye, R. A. The Evolution of the Concept of Medicalization in the Late Twentieth Century / R. A. Nye // Journal of History of the Behavioral Sciences. - 2003. - Vol. 39 (2). - P. 115-129.

54. Parsons, T. The Social System / T. Parsons. Glencoe, Ill. : The Free Press, 1951. -600 p.

55. Payer, L. Disease-mongers: How Doctors, Drug Companies, and Insurers are Making You Feel Sick / L. Payer. - N. Y. : John Wiley and Sons, 1992.$324 \mathrm{p}$.

56. Szasz, T. The Medicalization of Everyday Life: Selected Essays / T. Szasz. - Syracuse, N. Y. : Syracuse University Press, 2007. - 202 p.

57. Zola, I. Medicine as an Institute of Social Control / I. Zola // Sociological Review. New Series. 1972. - Vol. 20 (4). - P. 487-504.

\section{REFERENCES}

1. Atagadzhieva M.S. Sotsialnye i klinicheskie osobennosti medikalizatsii predmenstrualnogo sindroma: avtoref. dis. ... kand. med. nauk [Social and Clinical Characteristics of the Medicalization of Premenstrual Syndrome. Cand. med. sci. abs. diss.]. Volgograd, 2010.27 p.

2. Baraulina T. Moralnoe materinstvo i vosproizvodstvo zhenskogo opyta [Moral Motherhood and the Reproduction of the Female Experience]. Zdravomyslova E., Temkina A. Vpoiskakh seksualnosti: sb. st. [In Search of Sexuality: Collected Articles]. Saint Petersburg, Dmitriy Bulanin Publ., 2002, pp. 366-405.

3. Basov A.V. Farmatsevticheskie kompanii kak sotsialnye agenty medikalizatsii: avtoref. dis. ... kand. sotsiol. nauk [Pharmaceutical Companies as Social Agents of Medicalization. Cand. sociol. sci. abs. diss.]. Volgograd, 2008. $26 \mathrm{p}$.

4. Bek U. Obshchestvo riska. Na puti k drugomu modernu [The Risk Society. On the Way to Another Modernity]. Moscow, Progress-Traditsiya Publ., 2000. $383 \mathrm{p}$.

5. Boyazitova A.N. Medikalizatsiya kak sotsialnyy protsess: avtoref. dis. ... kand. med. nauk [The Medicalization as a Social Process. Cand. med. sci. abs. diss.]. Volgograd, 2007. $30 \mathrm{p}$.

6. Budarin G.Yu. Sotsialnye printsipy normativnogo regulirovaniya meditsinskoy deyatelnosti: avtoref. dis. ... kand. sotsiol. nauk [The Social Principles of Medical Activities Control. Cand. sociol. sci. abs. diss.]. Volgograd, 2002. 27 p. 
7. Verminenko Yu.V. Sotsiologicheskaya interpretatsiya zdorovya [Sociological Interpretation of Health]. Sotsialnye problem, 2008, no. 1, pp. 37-44.

8. Veshneva S.A. Medikalizatsiya narkomanii $i$ sotsializatsiya narkozavisimykh: kontseptsiya $i$ vzaimosvyaz. avtoref. dis. ... d-ra. med. nauk [The Medicalization of Drug Addiction and Socialization of Drug Addicts: Conception and Interrelation. Dr. med. sci. abs. diss.]. Volgograd, 2016. 47 p.

9. Vystuplenie Prezidenta Rossiyskoy Federatsii V.V. Putina na rasshirennom zasedanii Gosudarstvennogo soveta «O strategii razvitiya Rossii do 2020 goda» [Speech of President of the Russian Federation V.V. Putin at the Enlarged Meeting of the State Council "On the Development Strategy of Russia till 2020"]. Intellektualnaya sobstvennost. Promyshlennaya sobstvennost, 2008, no. 4, pp. 4-20.

10. Duganov M.D., Shabunova A.A., Kalashnikov K.N. Opyt postindustrialnykh stran v restrukturizatsii meditsinskoy pomoshchi i uroki dlya Rossii [The Experience of Post-Industrial Countries in Restructuring the Medical Care Sphere and Lessons for Russia]. Problemy razvitiya territorii, 2016, no. 2 (82), pp. 65-81.

11. Durkheim Й. Sotsiologiya. Ee predmet, metod, prednaznachenie [Sociology. Its Subject, Method, Purpose]. Moscow, Kanon Publ., 1995. 352 p.

12. Zdravomyslova E.A., Temkina A.A. «Vracham ya ne doveryayu, no...» Preodolenie nedoveriya $k$ reproduktivnoy meditsine ["I Don't Trust Doctors, but..." Overcoming Distrust in Reproductive Medicine]. Saint Petersburg, Izd-vo EUSPb, 2009, pp. 179-210.

13. Karpov A.M. Zdravstvuyte, esli khotite. Obrazovatelnye osnovy integratsii meditsiny, ekologii, obraza zhizni $i$ vlasti [Hello, If You Want. Educational Basics of Integration of Medicine, Ecology, Lifestyle and Government]. Kazan, Med. lit. Publ., 2008. 224 p.

14. Kesaeva R.E. Sotsiologicheskiy analiz mediko-sotsialnoy raboty s pozhilymi lyudmi: avtoref. dis. ... kand. sotsiol. nauk [A Sociological Analysis of Medical Social Work With Older People. Cand. sociol. sci. abs. diss.]. Volgograd, 2008. 25 p.

15. Gvishiani D.M., Lapina N.I., eds. Kratkiy slovar po sotsiologii [A Concise Dictionary of Sociology]. Moscow, Politizdat Publ., 1988. 77 p.

16. Kuznetsov A.V. Sotsialnye vzaimodeystviya vrachey, patsientov i SMI v protsesse medikalizatsii: avtoref. dis. ... kand. sotsiol. nauk [Social Interaction Between Doctors, Patients and the Media in the Process of Medicalization. Cand. sociol. sci. abs. diss.]. Volgograd, 2009.27 p .

17. Lehcier V.L. Effekty medikalizatsii i apologiya patosa [The Effects of Medicalization and Apologia for Pathos]. Vestnik Samarskoy gumanitarnoy akademii. Ser. «Filosofiya. Filologiya», 2006, no. 1 (4), pp. 113-125.

18. Makarova O.S. Lingvisticheskiy aspekt medikalizatsii: postanovka problemy [The Linguistic Aspect of Medicalization: Problem Statement]. Uchenye zapiski Novgorodskogo gosudarstvennogo universiteta imeni Yaroslava Mudrogo, 2015, no. 2, pp. 10-11.

19. Myzgin A.V., Andeeva A.V., Shevtsova E.P., Shatilova Yu.A. Medikalizatsiya beremennosti [The Medicalization of Pregnancy]. Mat i ditya v Kuzbasse, 2014, no. 3 (58), pp. 12-15.

20. Mikhaylova O.N. Medikalizatsiya detstva: sotsiologicheskiy analiz: avtoref. dis. ... kand. med. nauk [The Medicalization of Childhood: a Sociological Analysis. Cand. med. sci. abs. diss.]. Volgograd, 2008. $23 \mathrm{p}$.

21. Mihel D.V. Medikalizatsiya kak sotsialnyy fenomen [The Medicalization as a Social Phenomenon]. Vestnik SGTU, 2011, no. 4 (60), iss. 2, pp. 256-263.

22. Myzgin A.V. Sotsialnye riski medikalizatsii beremennosti: avtoref. dis. ... kand. sotsiol. nauk [Social Risks of Pregnancy Medicalization. Cand. sociol. sci. abs. diss.]. Volgograd, 2012. 24 p.

23. Petrov V.I., Lutsevich A.N., Reshetko O.V. Novye tekhnologii, regulirovanie, standartizatsiya $i$ farmakoekonomika $v$ sfere obrashcheniya lekarstvennykh sredstv [New Technology, Regulation, Standardization and Pharmacoeconomics in the Field of Medicines]. Moscow, Meditsina Publ., 2006. 456 p.

24. Figueras J., McKee M., Mossialos E., Saltman R.B. Reforma bolnits v novoy Evrope [The Reform of Hospitals in the New Europe]. Moscow, Ves Mir Publ., $2002.320 \mathrm{p}$.

25. Reshetnikov A.V. Sotsiologiya meditsiny [Sociology of Medicine]. Moscow, GEOTAR-Media, 2007.256 p.

26. Rivkin-Fish M., Samokhvalov V. Seksualnoe obrazovanie i razvitie lichnosti: pereosmyslenie professionalnoy vlasti [Sex Education and Personal Development: Rethinking Professional Power]. Saint Petersburg, Izd-vo Evrop un-ta v S.-Peterburge, 2009, pp. 21-51.

27. Sasunkevich O.M. Medikalizatsiya diskursa o materinstve $\mathrm{v}$ belorusskikh media [The Medicalization of Discourse on Motherhood in Belarusian Media]. Zhurnal issledovaniy sotsialnoy politiki, 2014, vol. 7, no. 3, pp. 405-418.

28. Sotsialnye determinanty zdorovya [Social Determinants of Health]. URL: http://www.who.int/ social_determinants/ru/ (accessed January 13, 2017).

29. Temkina A. Medikalizatsiya reproduktsii i rodov: borba za kontrol [The Medicalization of Reproduction and Childbirth: a Struggle for Control]. Zhurnal issledovaniy sotsialnoy politiki, 2014, vol. 12, no. 3, pp. 321-336. 
30. Terentyev O.V. Zdorovye cheloveka kak obyekt filosofskogo-aksiologicheskogo analiza: avtoref. dis. ... kand. filos. nauk [Human Health as an Object of Philosophical-Axiological Analysis. Cand. philos. sci. abs. diss.]. Moscow, 2008. 26 p.

31. Fillips L., Jorgensen M. V. Diskurs-analiz: teoriya $i$ metod [Discourse Analysis: Theory and Method]. Kharkov, Gumanitarnyy tsentr Publ., 2008. $336 \mathrm{p}$.

32. Fuko M. Istoriya bezumiya v klassicheskuyu epokhu [History of Madness in the Classical Age]. Saint Petersburg, Universitetskaya kniga Publ., 1997. $576 \mathrm{p}$.

33. Fuko M. Rozhdenie kliniki [The Birth of the Clinic]. Moscow, Smysl Publ., 1998. 310 p.

34. Fuko M. Rozhdenie sotsialnoy meditsiny [The Birth of Social Medicine]. Intellektualy $i$ vlast: Izbrannye politicheskie statyi, vystupleniya $i$ intervyu. Ch. 3 [Intellectuals and Power: Selected Political Articles, Speeches and Interviews. Part 3]. Moscow, Praksis Publ., 2006, pp. 79-107.

35. Chernyshkova E.V., Andriyanova E.A. Aktivnyy obraz zhizni v pozhilom vozraste: medikosotsialnye strategii, riski, praktiki [Active Lifestyle in Old Age: Medico-Social Strategies, Risks, Practices]. Saratov, Nauka Publ., 2012. 258 p.

36. Shlyumbom Yu., Hagner M., Sirotkina I. Vvedenie. Istoriya meditsiny: aktualnye tendentsii i perspektivy [Introduction. History of Medicine: Current Trends and Prospects]. Bolezn i zdorovye: novye podkhody $k$ istorii meditsiny [Sickness and Health: New Approaches to the History of Medicine]. Saint Petersburg, Aletheia Publ., 2008, pp. 155-160.

37. Shukhatovich V.R. Medikalizatsiya [Medicalization]. Gritsanov A.A., Abushenko V.L., Evelkin G.M. et al. Sotsiologiya: entsiklopediya [Sociology: Encyclopedia]. Minsk, Knizhnyy Dom Publ., 2003, p. 1312.

38. Conrad P., Schneider J.W. Deviance and Medicalization: From Badness to Sickness. Philadelphia, Temple University Press, 1992, pp. 263-265.

39. Conrad P. Identifying Hyperactive Children: The Medicalization of Deviant Behavior. Burlington, Ashgate, 2006. 160 p.

40. Conrad P., Leiter V. Medicalization, Markets and Consumers. Journal of Health and Social Behavior, 2004, vol. 45 (Extra Issue), pp. 158-176.

41. Conrad P. The Discovery of Hyperkinesis: Notes on the Medicalization of Deviant Behavior. Social Problems, 1975, vol. 23 (1), pp. 12-21.
42. Conrad P. The Medicalization of Society: On theTransformation of Human Conditions into Treatable Disorders. Baltimore, The Johns HopkinsUniversity Press, 2007. 205 p.

43. Foucault M. Naissance de la clinique. Paris, Presses Universit. de France, 1963. 212 p.

44. Foucault M. The Politics of Health in the Eighteenth Century. Gordon C. (ed.) Power/ Knowledge: Selected Interviews and Other Writings, 1972-1977. New York, Pantheon Books, 1980, pp. 166-182.

45. Freidson E. Profession of Medicine: A Study of the Sociology of Applied Knowledge. New York, Dodd, Mead Gabe, 1970.419 p.

46. Illich I. Medical Nemesis. Journal of Epidemiology and Community Health, 2003, vol. 57 (12), pp. 919-922.

47. Illich I. Medical Nemesis: The Expropriation of Health. New York, Pantheon Books, 1976. 201 p.

48. Lock M., Nguyen V.-K. An Anthropology of Biomedicine. Oxford, Blackwell, 2010. pp. 303-347.

49. Lock M. Encounters with Aging: Mythologies of Menopause in Japan and North America. Berkeley, University of California Press, 1993. 439 p.

50. Lock M., Kaufert P., eds. Pragmatic Women and Body Politics. Cambridge, Cambridge University Press, 1998.364 p.

51. Lock M. Utopias of Health, Eugenics, and Germline Engineering. Nichter M., Lock M. (eds.) New Horizons in Medical Anthropology: Essays in Honour of Charles Leslie. Harwood Academic, 2002, pp. 239-266.

52. Martin E. The Woman in the Body: A Cultural Analysis of Reproduction. Boston, Beacon Press, 2001.276 p.

53. Nye R.A. The Evolution of the Concept of Medicalization in the Late Twentieth Century. Journal of History of the Behavioral Sciences, 2003, vol. 39 (2), pp. 115-129.

54. Parsons T. The Social System. Glencoe, The Free Press. $1951.600 \mathrm{p}$.

55. Payer L. Disease-mongers: How Doctors, Drug Companies, and Insurers are Making You Feel Sick. New York, John Wiley and Sons, 1992. $324 \mathrm{p}$.

56. Szasz T. The Medicalization of Everyday Life: Selected Essays. Syracuse, New York, Syracuse University Press, 2007, p. 202.

57. Zola I. Medicine as an Institute of Social Control. Sociological Review. New Series, 1972 , vol. 20 (4), pp. 487-504. 


\section{Information about the Authors}

Tatyana G. Svetlichnaya, Doctor of Medical Sciences, Professor, Professor of Department of Public Health, Health Care and Social Work, Northern State Medical University, Prosp. Troitskiy, 51, 163000 Arkhangelsk, Russian Federation, statiana64@yandex.ru.

Elena A. Smirnova, Candidate of Sociological Sciences, Associate Professor, Department of Sociology and Social Technologies, Cherepovets State University, Prosp. Sovetskiy, 8, 162600 Cherepovets, Russian Federation, Smirnova56@yandex.ru.

\section{Информация об авторах}

Татьяна Геннадьевна Светличная, доктор медицинских наук, профессор кафедры общественного здоровья, здравоохранения и социальной работы, Северный государственный медицинский университет, просп. Троицкий, 51, 163000 г. Архангельск, Российская Федерация, statiana64@yandex.ru.

Елена Алексеевна Смирнова, кандидат социологических наук, доцент кафедры социологии и социальных технологий, Череповецкий государственный университет, просп. Советский, 8 , 162600 г. Череповец, Российская Федерация, Smirnova56@yandex.ru. 